\title{
The effects of melatonin on plasma homocysteine and oxidative stress parameters in cisplatin-treated rats
}

\author{
Abdurrauf YÜCE ${ }^{1}$, Ahmet ATEŞŞAHİN ${ }^{2}$, Engin ŞAHNA ${ }^{3}$, Mesut AKSAKAL ${ }^{1}$ \\ ${ }^{1}$ Department of Physiology, ${ }^{2}$ Department of Pharmacology, Faculty of Veterinary Medicine; ${ }^{3}$ Department of Pharmacology, Faculty \\ of Medicine, Firat University Elazıg - Turkey
}

Summary: The aims of this study were to investigate the effects of cisplatin on nephrotoxicity, plasma homocysteine level and biochemical changes related to oxidative stress and to examine the possible protective role of melatonin administration on these parameters in cisplatin treated rats. In this study, eighteen adult rats were used. The rats were randomly divided into three groups. The first group of rats (control) served as untreated controls and received only physiological saline. The second group of rats (CP) was given cisplatin $(7 \mathrm{mg} / \mathrm{kg})$ intraperitoneally. Group third of rats received cisplatin $(7 \mathrm{mg} / \mathrm{kg})$ and melatonin $(10 \mathrm{mg} / \mathrm{kg})(\mathrm{CP}+\mathrm{Mel})$ intraperitoneally. Administration of cisplatin to rats induced a marked renal failure, characterized with a significantly increase in plasma creatinine and urea concentrations. While the plasma malondialdehyde level significantly increased, the plasma homocysteine, glutathione levels and glutathione peroxidase, catalase activities significantly decreased in CP group when compared to control group. Although the administration of melatonin to cisplatin treated animals significantly increased the plasma levels of antioxidant enzymes, and decreased markedly the plasma malondialdehyde level, it has no any significant effect on plasma homocysteine level compared to alone cisplatin group. However, melatonin decreased the plasma homocysteine level compared to the control group. This study indicated that melatonin ameliorated the cisplatin-induced oxidative stress, which had the harmful effect on the renal function. However; it was ineffective on plasma homocysteine level in cisplatin-treated rats.

Key words: Cisplatin, homocysteine, melatonin, nephrotoxicity, oxidative stress, rat.

\section{Sisplatin uygulanan ratlarda plazma homosistein ve oksidatif stres parametreleri üzerine melatoninin etkileri}

Özet: Bu çalışmada sisplatin uygulan ratlarda oksidatif stres ile ilişkili biyokimyasal değişimler, plazma homosistein düzeyi ve nefrotoksisite üzerine melatoninin etkisi araştırılmıştır. Bu çalışmada 18 erişkin rat kullanıldı. Ratlar rasgele 3 gruba ayrıldı. Birinci grup ratlara (kontrol) sadece serum fizyolojik uygulaması yapıldı. Ikinci grup ratlara (CP) intraperitonal olarak sisplatin (7 $\mathrm{mg} / \mathrm{kg})$ uyguland. Üçüncü grup ratlara sisplatin $(7 \mathrm{mg} / \mathrm{kg})$ ve melatonin $(10 \mathrm{mg} / \mathrm{kg})(\mathrm{CP}+\mathrm{Mel})$ intraperitonal olarak uygulandı. Ratlara sisplatin uygulaması plazma kreatin ve üre konsantrasyonlarının önemli derecede artışıla karakterize belirgin bir renal bozukluk oluşturdu. Kontrol grubuyla karşılaştırıldığında sisplatin grubunda glutasyon peroksidaz ve katalaz aktivitesinde plazma homosistein ve glutasyon düzeylerinde önemli bir azalma görülürken, plazma malondialdehid düzeyinde önemli derecede bir artış belirlenmiştir. Sadece sisplatin verilen ve sisplatin ve melatoninin birlikte verildiği gruplar karşılaştırıldığında, plazma malondialdehid düzeyi önemli derecede azalırken plazma antioksidan enzim aktivitesi artmış plazma homosistein düzeyinde ise bir değişim saptanmamıştır. Ancak kontrol grubuyla karşılaştırıldığında plazma homosistein düzeyini melatoninin düşürdüğü görülmüştür. Bu çalışmada, melatoninin sisplatinin neden olduğu oksidatif stres ve renal bozukluklar üzerine iyileştirici etkisi bulunduğu, plazma homosistein düzeyleri üzerine ise etkisiz olduğu tespit edilmiştir.

Anahtar sözcükler: Homosistein, melatonin, nefrotoksisite, oksidatif stres, rat, sisplatin.

\section{Introduction}

Homocysteine (Hcy) is a sulphur-containing amino acid that is generated from metabolism of methionine. Hcy does not occur in the diet but it is an essential intermediate product in normal metabolism of methionine. Cellular levels of Hcy are regulated by availability of methionine, remethylation of Hcy to methionine, and transsulfuration of Hcy to cysteine. (11).

Plasma concentrations of $\mathrm{Hcy}$ are regulated by genetic and dietary factors, and are higher in males than females (15). It is believed to exert several toxic effects.
Hcy is considered as a risk factor for arteriosclerosis, in particular for cardiovascular disease (8). There is a significant relationship between plasma Hcy levels and lipid peroxidation. The high plasma levels of Hcy leads to endothelial injury and dysfunction by free radicals generated during the oxidation of Hcy (6). Hcy also inhibits the growth of vascular endothelial cells and alters regulatory proteins associated with cell membrane (9).

Cisplatin (cis-diamminedichloroplatinum II, CP) is currently one of the most important cytostatic agents in treatment of a wide range of solid tumours. However, the 
clinical usefulness of this drug is limited by the development of nephrotoxicity, a side effect that may be produced in various animal models $(13,16,29)$. The xenobiotic-induced alterations in kidney functions are characterized by signs of injury, such as changes in urine volume, creatinine clearance, in glutathione (GSH) status, increase of lipid peroxidation (LPO). Formation of free radicals, leading to oxidative stress, has been shown to be one of the main pathogenic mechanisms of these toxicities and side effects of nephrotoxicants $(1,2)$. CPinduced nephrotoxicity is also closely associated with an increase in LPO in the kidney tissues. This antitumoural drug causes generation of reactive oxygen species (ROS), such as hydrogen peroxide $\left(\mathrm{H}_{2} \mathrm{O}_{2}\right)$, superoxide anion $\left(\mathrm{O}_{2}{ }^{-}\right)$ and hydroxyl radical $(\mathrm{OH})$, to deplete of glutathione (GSH) levels and to inhibit the activity of antioxidant enzymes including superoxide dismutase (SOD), catalase (CAT) and glutathione peroxidase (GSH-Px) in renal tissue. ROS may produce cellular injury and necrosis via several mechanisms including peroxidation of membrane lipids, protein denaturation and DNA damage $(16,21)$. Enzymatic and molecular defense mechanisms are present in the cell to prevent the integrity of biological membranes from oxidative processes caused by free radicals. The administration of antioxidants such as melatonin, Vitamin E, Vitamin $\mathrm{C}$, selenium and carotenoids, before or after treatment with $\mathrm{CP}$ has been used to protect or ameliorate against nephrotoxicity and testicular toxicity in human and animals $(3,20,22)$.

Melatonin (Mel), secretory product of the pineal gland, is a free radical scavenger and an effective antioxidant (25). Mel represents the most potent physiological scavenger of ROS. Mel acts as a primary non-enzymatic antioxidative defense against the devastating actions of the extremely reactive hydroxyl radical (14).

The aims of this study were to investigate the effects of $\mathrm{CP}$ on plasma Hcy levels and biochemical changes related to oxidative stress and to examine the protective role of Mel administration on these parameters in CP-treated rats.

\section{Material and Methods}

\section{Chemicals}

CP $(10 \mathrm{mg} / 10 \mathrm{ml}$, Code $1876 \mathrm{~A})$ was purchased from Faulding Pharmaceuticals Plc (Warwickshire, UK), Mel $\left(\mathrm{C}_{13} \mathrm{H}_{16} \mathrm{~N}_{2} \mathrm{O}_{2}\right.$, pure crystalline powder, M5250) and the other chemicals were obtained from Sigma (St Louis, MO, USA).

\section{Animals and treatment}

In this investigation, 18 healthy adult male SpragueDawley rats (8 weeks old weighing 210-250g) were used.
The animals were obtained from the Firat University Medical School, Experimental Research Centre, Elazığ, Turkey. The animals were kept under standard laboratory conditions (12 hours light, 12 hours dark and $24 \pm 3^{\circ} \mathrm{C}$ ). The rats were fed standard commercial laboratory chow (pellet form, in the sack, Elazığ Food Company). Feed and water were provided ad libitum. All experiments in this study were performed in accordance with the guidelines for animal research from the National Institutes of Health and were approved by the Local Committee on Animal Research.

The rats were randomly divided into three groups each group containing 6 rats. CP was injected to animals, intraperitoneally at the dose of $7 \mathrm{mg} / \mathrm{kg}$, which is well documented to induce nephrotoxicity in rats $(1,30)$. Mel was dissolved in ethanol (10\%) and further diluted in saline $(0.9 \% \mathrm{NaCl}, 1 \mathrm{~mL})$ to give a final concentration of $1 \%$, and it was administered to animals, i.p. at the dose of $10 \mathrm{mg} / \mathrm{kg}$. The first group (control) received a single dose i.p. injection of $1 \mathrm{~mL}$ isotonic saline. The second group (CP) received a single dose $\mathrm{CP}$. The third group $(\mathrm{CP}+\mathrm{Mel})$ received Mel i.p. $24 \mathrm{~h}$ prior to $\mathrm{CP}$ and continued for 4 days after $\mathrm{CP}$ administration.

\section{Necropsy}

At the end of experimental period, the rats were decapitated. Blood samples were collected into tubes containing sodium oxalate ( $2 \%$ ) and centrifuged at 3.000 rpm for $10 \mathrm{~min}$. Plasma were stored at $-20^{\circ} \mathrm{C}$ until biochemical analyses.

\section{Homocysteine, creatinine and urea}

Total plasma Hcy levels were determined with enzyme immunoassay kit (Axis-Shield AS, Oslo, Norway). The plasma Hcy level was expressed as $\mu \mathrm{mol} / \mathrm{mL}$. Plasma creatinine and urea concentrations were measured by using auto analyzer (Olympus AU 600, Japan).

\section{Lipid Peroxidation}

Plasma lipid peroxidation (LPO) level was measured according to the concentration of thiobarbituric acid reactive species (23). The amount of malondialdehyde (MDA) produced was used as an index of lipid peroxidation. Briefly, one volume of the test sample and two volume of stock reagent $(15 \%, \mathrm{w} / \mathrm{v}$ trichloroacetic acid in $0.25 \mathrm{~N} \mathrm{HCl}$ and $0.375 \%$, w/v thiobarbituric acid in $0.25 \mathrm{~N} \mathrm{HCl}$ ) were mixed in a centrifuge tube. The solution was vortexed and heated for $15 \mathrm{~min}$ in boiling water. After cooling, the precipitate was removed by centrifugation at $2500 \mathrm{rpm}$ for $10 \mathrm{~min}$ and then absorbance of the supernatant was measured at $532 \mathrm{~nm}$ against a blank containing all reagents except test sample. The concentration of lipid peroxidation was expressed as $\mathrm{nmol} / \mathrm{mL}$. 


\section{Catalase}

Plasma CAT activity was measured as previously described by Goth (12). Briefly, $0.2 \mathrm{ml}$ of plasma samples was incubated in $1.0 \mathrm{ml}$ substrate $(65 \mu \mathrm{mol}$ per $\mathrm{ml}$ hydrogen peroxide in $50 \mathrm{mM}$ phosphate buffer, $\mathrm{pH}$ 7.0 ) at $37{ }^{\circ} \mathrm{C}$ for $60 \mathrm{~s}$. The enzymatic reaction was terminated with $1.0 \mathrm{~mL}$ of $32.4 \mathrm{mM}$ ammonium molybdate. Hydrogen peroxide was measured at $405 \mathrm{~nm}$ against blank containing all the components except the enzyme on a spectrophotometer (Shimadzu 2R/UVvisible, Tokyo, Japan). The catalase activity was expressed as KU/L.

\section{Glutathione peroxidase}

GSH-Px activities of plasma samples were determined according to the method of Lawrence and Burk (18). The reaction mixture consisted of $50 \mathrm{mM}$ potassium phosphate buffer ( $\mathrm{pH}$ 7.0), 1 mM EDTA, 1 mM sodium azide $\left(\mathrm{NaN}_{3}\right), 0.2 \mathrm{mM}$ reduced nicotinamide adenine dinucleotide phosphate (NADPH), 1 E.U./ml oxidized glutathione (GSSG)-reductase, $1 \mathrm{mM} \mathrm{GSH}$, and $0.25 \mathrm{mM} \mathrm{H}_{2} \mathrm{O}_{2}$. Enzyme source $(0.1 \mathrm{ml})$ was added to 0.8 $\mathrm{ml}$ of the above mixture and incubated for $5 \mathrm{~min}$ at $25^{\circ} \mathrm{C}$ before initiation of the reaction with the addition of 0.1 $\mathrm{ml}$ of peroxide solution. The absorbance at $340 \mathrm{~nm}$ was recorded for $5 \mathrm{~min}$. The activity was calculated from the slope of the lines as micromoles of NADPH oxidized per minute. The blank value (the enzyme was replaced with distilled water) was subtracted from each value. Results were expressed as IU/g protein. Protein concentrations were measured by the method (19).

\section{Reduced Glutathione}

The GSH content of the liver and heart homogenate was measured at $412 \mathrm{~nm}$ using the method of Sedlak and Lindsay (27). The samples were precipitated with $50 \%$ trichloraacetic acid and then centrifuged at $1000 \mathrm{rpm}$ for $5 \mathrm{~min}$. The reaction mixture contained $0.5 \mathrm{ml}$ of supernatant, $2.0 \mathrm{ml}$ of Tris-EDTA buffer ( $0.2 \mathrm{M}$; $\mathrm{pH} 8.9)$ and $0.1 \mathrm{ml}$ of $0.01 \mathrm{M} \mathrm{5.5}$ '-dithio-bis-2-nitrobenzoic acid. The solution was kept at room temperature for $5 \mathrm{~min}$, and then read at $412 \mathrm{~nm}$ on the spectrophotometer.

\section{Statistical Analyses}

All values are presented as mean \pm SEM. Differences were considered to be significant at $\mathrm{p}<0.05$. Statistical analyses were performed using One-way analysis of variance (ANOVA) and post hoc Tukey-HSD test using SPSS/PC computer program.

\section{Results}

The levels of plasma Hcy, MDA, GSH, creatinine and urea as well as GSH-Px and CAT activities are shown in Table 1. The plasma MDA, creatinine and urea levels significantly $(\mathrm{p}<0.01)$ increased in CP-treated animals when compared to control animals. However, the administration of $\mathrm{Mel}$ to $\mathrm{CP}$-treated animals when compared to $\mathrm{CP}$ group significantly $(\mathrm{p}<0.01)$ reduced the plasma MDA, creatinine and urea levels.

Table 1. The values of plasma Malondialdehyde (MDA), Gluthatione (GSH), Gluthatione Peroxidase (GSH-Px), Catalase, Homocysteine, Creatinine and Urea in all groups.

Tablo 1. Bütün gruplarda Malondialdehit (MDA), Glutasyon (GSH), Glutasyon Peroksidaz (GSH-Px), Katalaz, Homosistein, Kreatin va Üre plazma değerleri.

\begin{tabular}{|c|c|c|c|}
\hline & Control & Cisplatin & $\begin{array}{c}\text { Cisplatin } \\
+ \\
\text { Melatonin }\end{array}$ \\
\hline $\begin{array}{l}\text { Homocsteine } \\
(\mu \mathrm{mol} / \mathrm{L})\end{array}$ & $12.34 \pm 0.774^{\mathrm{a}}$ & $8.41 \pm 0.798^{b}$ & $9.67 \pm 0.402^{\mathrm{b}}$ \\
\hline $\begin{array}{c}\mathrm{MDA} \\
(\mathrm{nmol} / \mathrm{ml})\end{array}$ & $1.61 \pm 0.11^{\mathrm{a}}$ & $2.42 \pm 0.11^{\mathrm{b}}$ & $1.56 \pm 0.06^{\mathrm{a}}$ \\
\hline $\begin{array}{c}\mathrm{GSH} \\
(\mu \mathrm{mol} / \mathrm{ml})\end{array}$ & $0.235 \pm 0.004^{\mathrm{a}}$ & $0.140 \pm 0.003^{b}$ & $0.242 \pm 0.003^{\mathrm{a}}$ \\
\hline $\begin{array}{c}\text { GSH-Px } \\
\text { (IU/g protein) }\end{array}$ & $6.66 \pm 0.49^{\mathrm{a}}$ & $5.39 \pm 0.23^{\mathrm{b}}$ & $7.53 \pm 0.22^{\mathrm{a}}$ \\
\hline $\begin{array}{c}\text { Catalase } \\
(\mathrm{kU} / \mathrm{L})\end{array}$ & $31.44 \pm 4.21^{\mathrm{A}}$ & $18.98 \pm 2.02^{\mathrm{B}}$ & $25.22 \pm 3.04^{\mathrm{AB}}$ \\
\hline $\begin{array}{l}\text { Creatinine } \\
(\mathrm{mg} / \mathrm{dl})\end{array}$ & $0.54 \pm 0.07^{\mathrm{a}}$ & $0.97 \pm 0.11^{\mathrm{b}}$ & $0.63 \pm 0.11^{\mathrm{a}}$ \\
\hline $\begin{array}{l}\text { Urea } \\
(\mathrm{mg} / \mathrm{dl})\end{array}$ & $41 \pm 3.9^{\mathrm{a}}$ & $107 \pm 5.1^{\mathrm{b}}$ & $67 \pm 3.9^{c}$ \\
\hline
\end{tabular}

Different lowercases $\left({ }^{\mathrm{a}, \mathrm{b}, \mathrm{c}} ; \mathrm{p}<0.01\right)$ and uppercases $\left({ }^{\mathrm{A}, \mathrm{B}}\right.$; $\mathrm{p}<0.05$ ) in the same line show significant differences among the groups.

Plasma Hcy, GSH-Px, GSH $(\mathrm{p}<0.01)$ and CAT $(p<0.05)$ levels decreased significantly in CP group when compared to control group. On the other hand, the administration of Mel to CP-treated animals caused to significant $(p<0.05, p<0.01)$ increases in the plasma enzyme activities. Plasma Hcy levels were significantly decreased both $\mathrm{CP}$ group and $\mathrm{CP}+\mathrm{Mel}$ group when compared to control group. However, no difference was observed in the plasma Hcy level between CP and $\mathrm{CP}+\mathrm{Mel}$ group.

\section{Discussion and Conclusion}

Effective anticancer therapy with cytotoxic drugs is limited by several organ toxicity including kidneys, inner ear, peripheral nerves, testicular tissue $(4,26)$. The impairment of kidney function by $\mathrm{CP}$ is recognized as the main side effect and the most important dose-limiting factor associated with its clinical use. Several investigators $(13,22)$ reported that the alterations induced by $\mathrm{CP}$ in the kidney functions were characterized by signs of injury, such as increase of products of LPO and changes in GSH levels, creatinine and urea levels in plasma. In the present study, administration of $\mathrm{CP}$ caused increases in the plasma MDA which is an indicator for 
LPO, creatinine and urea levels. The impairment in kidney function was accompanied by an increase in MDA concentrations in plasma. These observations indicated that CP induced nephrotoxicity and, our results were in accordance with those of above workers.

$\mathrm{Mel}$, secretory product of the pineal gland, is a free radical scavenger and an effective antioxidant $(24,25)$. Some study (10) has demonstrated that administration of Mel as an antioxidant against detrimental effects of various substances reduced the damage inflicted by aggressive radical species. Mel was shown to be a very efficient neutralizer of $\cdot \mathrm{OH}$, and also stimulates GSH-Px activity. GSH-Px metabolizes reduced glutathione to its oxidized form and in doing so it converts $\mathrm{H}_{2} \mathrm{O}_{2}$ to $\mathrm{H}_{2} \mathrm{O}$, thereby reducing generation of the $\cdot \mathrm{OH}$ by eliminating its precursor (24). Bouzouf et al. (7) reported that MDA levels were significantly increased in methionine-treated rats compared with control rats, whereas Mel prevented the increases in MDA levels. Our data indicated that although the administration of Mel to CP treated animals decreased markedly the plasma MDA, creatinine and urea levels compared to alone $\mathrm{CP}$ group. The ameliorations in MDA, creatinine and urea levels of $\mathrm{CP}+\mathrm{Mel}$ group rats are due to the potent free radical scavenging ability of Mel, which prevents the injuries caused by $\mathrm{CP}$-induced oxidative stress in kidney function.

$\mathrm{CP}$ is able to generate reactive oxygen species, and that is also inhibits the activity of antioxidant enzymes such as SOD, CAT and GSH-Px $(16,20,22)$. In this study, it was observed that GSH-Px and CAT activities decreased in CP-treated rats. The selenium-containing enzyme GSH-Px, scavenges hydroperoxides and lipid peroxides, protects cells against ROS. It is clear from this study that Mel treatment restored $\mathrm{CP}$ induced impairment in GSH-Px, CAT activities compared to only $\mathrm{CP}$ received group. Dose-limiting toxicity of the antitumour agents is mainly attributed to the inability of these drugs to differentiate between normal and tumour cells. Protective agents have been developed to reduce the damage associated with antitumour drugs by providing site-specific protection for normal tissues, without affecting the antitumour efficacy $(1,28)$.

One of the most important intracellular antioxidant systems is the GSH redox cycle. GSH is one of the essential compounds for maintaining cell integrity because of its reducing properties and participation in the cell metabolism. The depletion in the renal GSH level has been observed in rats in response to oxidative stress caused by CP treatment $(3,16)$. On the other hand, results of some investigators showed that the kidney damage caused by CP is not associated with decreased in GSH levels (13) or may cause increase in GSH levels
(21). The mechanism of this antitumoural drug-induced change in renal GSH level is not completely understood. However, GSH may modulate metal reduction and the thiol portion is very reactive with several compounds, mainly with alkylating agents such as CP. In this study, plasma GSH levels of rats treated with CP were lower than control group. On the other hand, an increase observed in GSH levels of $\mathrm{CP}+\mathrm{Mel}$ group rats in the present study. The effects of Mel on cellular GSH may be due to directly antioxidant effects, enhanced biosynthesis of GSH or increase in levels of other antioxidants such as Vitamin A, Vitamin E $(16,28)$.

Sulfur-containing amino acids such as cysteine, methionine, N- acetylcysteine and DL-Hcy inhibit CP nephrotoxicity and uptake in cultured renal cells. Two potential mechanisms for this inhibition had been explained by Kröning et al. (17) as; (a) the complex of $\mathrm{CP}$ and sulphur-containing aminoacids outside of the cell which could render it unsuitable to pass the cell membrane, (b) CP may share a renal cell transporter that is specific for the transport of sulfur-containing aminoacids. In this study, it was observed that the plasma Hcy level significantly reduced in both $\mathrm{CP}$ and $\mathrm{CP}+\mathrm{Mel}$ groups compared to the control group. This reduction was probably explained with the mechanisms mentioned above. Mel reduces the toxicity and efficacy of anticancer drugs (26). Plasma Hcy levels in animals treated with Mel were significantly lower than those of controls in the present study. Similarly, Baydas et al. (5) reported that plasma MDA and Hcy levels decreased significantly in Mel-treated animals, and Mel administration had a beneficial effect on decrease in plasma Hcy levels. In the present study, it was also found that the plasma Hcy level of $\mathrm{CP}+\mathrm{Mel}$ group was numerically higher than only received CP group, but the difference was not statistically significant. Although this status was probably attributed to the abolishment of efficacy of CP by Mel, further investigation is needed in this subject.

In conclusion, this study indicated that melatonin ameliorated the cisplatin-induced oxidative stress which had the harmful effect on the renal function. However; it was ineffective on plasma homocysteine level in cisplatin-treated rats.

\section{References}

1. Antunes LMG, Darin JDC, Bianchi MLP (2001): Effects of the antioxidants curcumin or selenium on cisplatin-induced nephrotoxicity and lipid peroxidation in rats. Pharmacol Res, 43, 145-150.

2. Ateşşahin A, Karahan I, Yılmaz S, Çeribaşı AO, Pirinççi İ (2003): The effect of manganese chloride on gentamicine-induced nephrotoxicity in rats. Pharmacol Res, 48, 637-642. 
3. Ateşşahin A, Şahna E, Türk G, Çeribaşı AO, Yılmaz S, Yuce A, Bulmuş O (2006): Chemoprotective effect of melatonin against cisplatin-induced testicular toxicity in rats. J Pineal Res, 41, 21-27.

4. Ateşşahin A, Yılmaz S, Karahan İ, Çeribaşı AO, Karaoglu A (2005): Effects of lycopene against cisplatininduced nephrotoxicity and oxidative stress in rats. Toxicology, 212, 116-123.

5. Baydaş G, Yılmaz O, Çelik S, Yaşar A, Gürsu MF (2002): Effects of certain micronutrients and melatonin on plasma lipid, lipid peroxidation, and homocysteine levels in rats. Arch Med Res, 33, 515-519.

6. Blom HJ, Kleinveld HA, Boers GH, Demacker PN, Hak-Lemmers HL, Te Poele-Pothoff MT, Trijbels JM (1995): Lipid peroxidation and susceptibility of lowdensity lipoprotein to in vitro oxidation in hyperhomocysteinaemia. Eur J Clin Invest, 25, 149-154.

7. Bouzouf M, Martinez-Cruz F, Molinero P, Guerrero JM, Osuna J (2005): Melatonin prevents hyperhomocysteinemia and neural lipid peroxidation induced by methionine intake. Curr Neurovasc Res, 2, 175-178.

8. Clarke R, Daly L, Robinson K, Naughten E, Cahalane S, Fowler B, Graham I (1991): Hyperhomocysteinemia: an independent risk factor for vascular disease. $\mathrm{N}$ Eng $\mathrm{J}$ Med, 324, 1149-1155.

9. Domagala TB, Undas A, Libura M, Szczeklik A (1998): Pathogenesis of vascular disease in hyperhomocysteinaemia. J Cardiovasc Risk, 5, 239-247.

10. El-Sokkary GH, Abdel-Rahman GH, Kamel ES (2005): Melatonin protects against lead-induced hepatic and renal toxicity in male rats. Toxicology, 213, 25-33.

11. Finkelstein JD, Martin JJ (2000): Homocysteine. Int J Biochem Cell Biol, 32, 385-389.

12. Goth L (1991): A simple method for determination of serum catalase activity and revision of reference range. Clin Chim Acta, 196, 143-152.

13. Greggi Antunes LM, Darin JD, Bianchi MP (2000): Protective effects of Vitamin $C$ against cisplatin-induced nephrotoxicity and lipid peroxidation in adult rats. Pharmacol Res, 41, 405-411.

14. Hardeland R, Reiter RJ, Poeggeler B, Tan DX (1993): The significance of the metabolism of the neurohormone melatonin: antioxidative protection and formation of bioactive substances. Neurosci Biobehav Rev, 17, 347-57.

15. Jacobsen DW, Gatautis VJ, Green R, Robinson K, Savon SR, Secic M, Ji J, Otto JM, Taylor LM (1994): Rapid HPLC determination of total homocysteine and other thiols in serum and plasma: sex differences and correlation with cobalamin and folate concentrations in healthy subjects. Clin Chem, 40, 873-881.

16. Kim YK, Jung JS, Lee SH, Kim YW (1997): Effects of antioxidants and $\mathrm{Ca}^{2+}$ in cisplatin-induced cell injury in rabbit renal cortical slices. Toxicol Appl Pharmacol, 146, 261-269.

17. Kröning R, Lichtenstein AK, Nagami GT (2000): Sulfur-containing amino acids decrease cisplatin cytotoxicity and uptake in renal tubule epithelial cell lines. Cancer Chemother Pharmacol, 45, 43-49.
18. Lawrence RA, Burk RF (1976): Glutathione peroxidase activity in selenium-deficient rat liver. Bioch Bioph Res Commun, 71, 952-958.

19. Lowry OH, Rosebrough NJ, Farr AL, Randall RI (1951): Protein measurement with folin phenol reagent. J Biol Chem, 193, 265-275.

20. Martinis BS, Bianchi MLP (2001): Effect of Vitamin C supplementation against cisplatin-induced toxicity and oxidative DNA damage in rats. Pharmacol Res, 44, 317320.

21. Mora LO, Antunes LM, Francescato HD, Bianchi MI (2003): The effects of oral glutamine on cisplatin-induced nephrotoxicity in rats. Pharmacol Res, 47, 517-522.

22. Nazıroğlu M, Karaoğlu A, Aksoy AO (2004): Selenium and high dose vitamin $\mathrm{E}$ administration protects cisplatininduced oxidative damage to renal, liver and lens tissues in rats. Toxicology, 195, 221-230.

23. Placer AZ, Linda LC, Johnson B (1966): Estimation of product of lipid peroxidation (malonyldialdehyde) in biochemical systems. Anal Biochem, 16, 359-64.

24. Reiter RJ, Melchiorri D, Sewerynek E, Poeggeler B, Barlow-Walden L, Chuang J, Ortiz GG, AcunaCastroviejo D (1995): A review of the evidence supporting melatonin's role as an antioxidant. J Pineal Res, 18, 1-11.

25. Reiter RJ, Tan DX, Allegra M (2002): Melatonin: reducing molecular pathology and dysfunction due to free radicals and associated reactants. Neuro Endocrinol Lett, 23, 3-8.

26. Reiter RJ, Tan DX, Sainz RM, Mayo JC, Lopez-Burillo S (2002): Melatonin: Reducing the toxicity and increasing the efficacy of drugs. J Pharm Pharmacol, 54, 1299-1321.

27. Sedlak J, Lindsay RH (1968): Estimation of total, protein-bound, and nonprotein sulfhydryl groups in tissue with Ellman's reagent. Anal Biochem, 25, 192-205.

28. Tapiero H, Townsend DM, Tew KD (2004): The role of carotenoids in the prevention of human pathologies. Biomed Pharmacother, 58, 100-110.

29. Weijl NI, Elsendoorn TJ, Lentjes EG, Hopman GD, Wipkink-Bakker A, Zwinderman AH, Cleton FJ, Osanto S (2004): Supplementation with antioxidant micronutrients and chemotherapy-induced toxicity in cancer patients treated with cisplatin-based chemotherapy: a randomised, double-blind, placebo-controlled study. Eur J Cancer, 40,1713-1723.

30. Yılmaz HR, Iraz M, Söğüt S, Özyurt H, Yıldırım Z, Akyol O, Gergerlioğlu S (2004): The effects of erdosteine on the activities of some metabolic enzymes during cisplatin-induced nephrotoxicity in rats. Pharmacol Res, 50, 287-290.

Geliş tarihi: 01.11.2006 / Kabul tarihi: 15.03.2007

Address for correspondence

Dr. Abdurrauf Yüce

Firat University

Faculty of Veterinary Medicine Department of Physiology

Elazıg / Turkey

e-mail:ayuce@firat.edu.tr 